\title{
Identifikasi Formalin pada Bakso yang Dijual pada Beberapa Tempat di Kota Padang
}

\author{
Faradila, Yustini Alioes, Elmatris
}

\begin{abstract}
Abstrak
Konsumsi makanan cepat saji saat ini telah menjadi kebiasaan makan bagi masyarakat Indonesia. Salah satu makanan cepat saji yang popular adalah bakso, namun saat ini sering dijumpai penggunaan bahan tambahan non pangan di dalam bakso yaitu formalin. Penggunaan formalin sudah dilarang dalam makanan berdasarkan peraturan Menteri Kesehatan No. 1168 tahun 1999, tetapi pada kenyataannya masih ada produsen makanan yang memproduksi makanan mengandung formalin. Salah satu makanan yang sering ditemukan berformalin adalah bakso. Tujuan penelitian ini adalah untuk mengidentifikasi apakah terdapat formalin pada bakso yang dijual di Kota Padang. 42 sampel yang diidentifikasi diambil dari pedagang bakso gerobak, warung bakso, serta rumah makan franchise di beberapa lokasi dengan jumlah pedagang bakso terbanyak. Pemeriksaan kualitatif dilakukan dengan menggunakan Test Kit Formalin yang terdiri atas cairan pereaksi I dan serbuk pereaksi II. Hasil penelitian menunjukkan bahwa 20 sampel dari 42 sampel yang diidentifikasi dilaboratorium positif mengandung formalin $(47,6 \%)$. Bedasarkan hasil yang didapatkan dapat disimpulkan bahwa hampir separuh bakso yang dijual di Kota Padang mengandung formalin.
\end{abstract}

Kata kunci: Bakso, Formalin

\begin{abstract}
Now a days, the consumption of fast food has become an eating pattern for Indonesian. One of the most popular fast food is meatball, but today, we often found that the producents add a non food addition ingredient in the meatball that we call formalin. The use of formalin actually has been prohibited used in food based on the Peraturan Menteri Kesehatan No.1168 tahun 1999, but in fact, there are food producent that produce food with formalin. One of the food is meat ball. The objective of this research is to identifying whether there are formalin in meatballs that sold in padang. 42 samples that identified taken from mobile vendor, meatball restaurant and franchise restaurant in several locations with the greatest numbers of meatball seller. The qualitative examination done by using the formalin test kit that contain of reagen I and reagen II. The result of the research conclude that 20 sample from 42 sample that has been identified in laboratorium are positive have formalin (47.6\%). Based on the result, we can conclude that almost of the bakso that has been sold in Padang contain formalin.
\end{abstract}

Keywords:Meatball, formalin

Affiliasi penulis : Fakultas Kedokteran Universitas Andalas Korespondensi : Faradila, email : faradila1991@hotmail.com, Telp 083181394563

\section{PENDAHULUAN}

Makanan cepat saji telah menjadi kebiasaan makan bagi generasi muda baik pelajar, mahasiswa, maupun para karyawan yang merupakan bagian terbesar dari populasi masyarakat Indonesia saat ini. Sisi praktis dan rasanya yang cukup lezat mungkin menjadi alas an sebagian besar masyarakat yang memilih mengonsumsi makanan cepat saji. ${ }^{1}$ Salah satu jenis makanan cepat saji yang popular adalah bakso karena harganya yang relative murah sehingga dapat terjangkau oleh masyarakat luas. ${ }^{2}$

Penggunaan pengawet non pangan pada bahan makanan saat ini sedang banyak dibicarakan. Berbagai tayangan televisi selalu menayangkan berbagai macam bentuk kecurangan yang dilakukan oleh pedagang makanan. Menurut Dr. Sri Durjati Boedihardjo bahan pengawet non pangan yang sering dipakai dan dijadikan bahan perbincangan saat ini adalah formalin. Biasanya formalin marak digunakan sebagai pengawet bahan makanan seperti: mie basah, tahu, ikan kering dan juga bakso. ${ }^{3}$

Berdasarkan beberapa penelitian menyatakan bahwa formalin tergolong sebagai karsinogen, yaitu senyawa yang dapat menyebabkan timbulnya kanker. ${ }^{4}$ Para ahli pangan sepakat bahwa semua bahan yang terbukti bersifat karsinogenik tidak boleh digunakan dalam bahan makanan maupun minuman. Prinsip ini di Amerika dikenal dengan nama Delaney Clause.

Menurut IPCS (International Programme on Chemical Safety), secara umum ambang batas aman didalam tubuh adalah 1 miligram per liter. Bila formalin masuk ke tubuh melebihi ambang batas tersebut, maka dapat mengakibatkan gangguan pada organ dan sistem tubuh manusia. Akibat yang ditimbulkan tersebut dapat terjadi dalam waktu singkat atau jangka pendek, dan dalam jangka panjang, baik melalui hirupan, kontak langsung atau tertelan. 6

Formalin sebenarnya sangat umum digunakan dalam kehidupan sehari-hari. Di sektor industri, formalin sangat banyak manfaatnya, misalnya sebagai anti bakteri atau pembunuh kuman, sehingga formalin sering dimanfaatkan sebagai pembersih lantai, kapal, gudang, pakaian bahkan juga dapat dipergunakan sebagai pembunuh lalat dan berbagai serangga lain. Dalam konsentrasi yang sangat kecil (< $1 \%$ ), formalin digunakan sebagai pengawet untuk berbagai bahan non pangan seperti pembersih rumah tangga, cairan pencuci piring, pelembut, shampo mobil, lilin dan karpet. ${ }^{7}$

Besarnya manfaat formalin dibidang industri ini, ternyata sering disalahgunakan untuk penggunaan pengawetan industri makanan. Salah satunya adalah makanan cepat saji bakso. Bakso adalah produk pangan yang terbuat dari bahan 
utama daging yang dilumatkan, baik daging ayam, babi ataupun sapi serta berbagai produk makanan laut seperti ikan, udang, dan kepiting, lalu dicampur dengan tepung kanji serta berbagai macam bumbu, lalu di bentuk bulatan-bulatan dan dkemudian di rebus. Salah satu parameter kualitas bakso adalah kekenyalannya. Biasanya konsumen menyukai bakso yang konsistensinya kenyal. Konsumen tidak menyukai bakso ataupun makanan lainnya yang berbau busuk, terasa seperti ammonia ataupun anyir. 8

Salah satu masalah terbesar bagi pengusaha bakso maupun makanan cepat saji adalah mencegah terjadinya pembusukan, karena itu makanan-makanan cepat saji harus habis terjual sebelum mengalami pembusukan. Masalah tersebut menyebabkan beberapa oknum penjual makanan cepat saji berbuat curang. Salah satu caranya adalah dengan mengawetkan makanan cepat saji tersebut yang umumnya mengandung protein dan lemak ataupun bahan bakunya dengan menggunakan formalin. Formalin tersebut bersifat mengkoagulasi protein yang terdapat dalam protoplasma dan nucleus sekaligus membunuh semua bakteri pembusuk yang ada pada bahan-bahan makanan tersebut. ${ }^{9}$

Penelitian ini dilakukan terhadap bakso yang dijual oleh pedagang-pedagang bakso baik pedagang bakso gerobak maupun warung bakso yang ada dibeberapa daerah Kota Padang. Sampel yang digunakan akan diambil dari pedagang bakso dengan produsen bakso yang berbeda. Setelah dilakukan survei lapangan, daerah-daerah dengan pedagang bakso paling banyak ada di Pasar Raya dan sekitarnya, serta Jati, Gunung Pangilun, dan Tabing. Tujuan dari penelitian ini adalah menentukan ada tidaknya kandungan formalin pada bakso yang dijual di Kota Padang.

\section{METODE}

Jenis penelitian adalah penelitian deskriptif. Populasi penelitian adalah seluruh pedagang bakso, baik pedagang bakso gerobak, warung bakso, maupun rumah makan franchise yang ada di Kota Padang. Sampel yang diambil berjumlah 42 sampel. Dari survei yang telah dilakukan peneliti, ditemukan ada 6 warung bakso dan 2 penjual bakso gerobak di daerah Jati, ditemukan 5 warung bakso dan 2 penjual bakso gerobak didaerah Gunung Pangilun, 5 warung bakso dan 10 penjual bakso gerobak didaerah Pasar Raya, serta ditemukan 6 warung bakso dan 3 pedagang bakso gerobak didaerah Tabing yang berasal dari produsen berbeda, serta di kota Padang terdapat 3 rumah makan franchise berbeda yang menjual bakso.

Sampel yang dikumpulkan dalam penelitian ini adalah sampel dar isetiap penjual bakso yang telah disurvei dan masing-masingnya diambil 1 sampel bakso sehingga terkumpul 42 sampel yang dilabel sebagai bakso gerobak (BG), bakso warung (BW), danbakso franchise (BF). Sampel tersebut disimpan didalam freezer dengan temperatur $-18^{\circ} \mathrm{C}$.

Penelitian dilaksanakan dari bulan Mei 2013 sampai September 2013, identifikasi formalin dilakukan di Laboratorium Biokimia Fakultas Kedokteran Universitas Andalas. Alat dan bahan yang digunakan untuk pemeriksaan laboratorium adalah tabung reaksi, rak tabung reaksi, kapas, lumpang, pipet tetes, bakso, air, serta Test Kit Formalin dengan merek Chemkit yang terdiri dari cairan pereaksi I formalin dan serbuk pereaksi II formalin. Langkahlangkah pemeriksaan laboratorium yang dilakukan yaitu sampel bakso yang telah diurut secara sistematis sesuai label diiris-iris tipis, lalu dimasukkan ke dalam lumpang dan ditambahkan 1 sendok makan air kemudian digiling, ambil $1 \mathrm{ml}$ cairan dari campuran dan masukkan kedalam tabung reaksi, teteskan 3-5 tetes cairan pereaksi I formalin, tutup tabung reaksi dengan menggunakan kapas, tambahkan $1 \mathrm{mg}$ serbuk pereaksi II formalin, kocok tabung reaksi, diamkan selama 5 menit. Lihat perubahan warna yang muncul. Bila terdapat perubahan warna menjadi ungu maka berarti bakso tersebut mengandung formalin.

\section{HASIL}

Dari 17 sampel bakso gerobak yang sudah diperiksa kandungan formalinnya didapatkan 6 sampel positif mengandung formalin dari 22 sampel bakso warung, 12 diantaranya positif mengandung formalin dan dari 3 sampel bakso franchise yang telah diperiksa, 2 diantaranya positif mengandung formalin.

Tabel 1. Frekuensi Bakso yang Mengandung Formalin

\begin{tabular}{lccc}
\hline & $\begin{array}{c}\text { Frekuensi Bakso } \\
\text { Ada atau Tidak ada } \\
\text { mengandung } \\
\text { formalin }\end{array}$ & $\begin{array}{c}\text { Total } \\
\text { Sampel }\end{array}$ & \\
\cline { 2 - 3 } Sampel & + & - & \\
\hline Bakso Gerobak & 6 & 11 & 17 \\
Bakso Warung & 12 & 10 & 22 \\
Bakso Franchise & 2 & 1 & 3 \\
\hline Total & 20 & 22 & 42 \\
\hline
\end{tabular}

\section{PEMBAHASAN}

Setelah dilakukan identifikasi formalin di laboratorium Biokimia Fakultas Kedokteran Universitas Andalas ternyata $35,29 \%$ bakso gerobak teridentifikasi mengandung formalin, $54,54 \%$ bakso warung teridentifikasi mengandung formalin, dan $66,67 \%$ bakso franchise teridentifikasi mengandung formalin.

Sesuai dengan pengamatan dilapangan ciriciri bakso yang mengandung formalin memangt hampir sama dengan bakso yang tidak mengandung formalin, namun jika diamati dengan seksama bakso yang mengandung formalin memiliki ciri-ciri fisik yang berbeda dengan bakso yang tidak mengandung formalin.

Hasil penelitian mengungkapkan bahwa bakso yang mengandung formalin warnanya terlihat lebih putih pucat dibandingkan dengan bakso yang tidak mengandung formalin namun jika dibelah didalamnya terlihat berwarna lebih merah. Hal ini disebakan karena senyawa formalin memiliki kandungan zat pemutih. ${ }^{10}$ Aroma dagingnya juga tidak terlalu kuat seperti bakso yang tidak mengandung formalin dan jika bakso yang mengandung formalin dilemparkan dia akan memantul, berbeda dengan bakso yang tidak mengandung formalin.

\section{KESIMPULAN}

Berdasarkan penelitian yang telah dilakukan terhadap 42 sampel bakso yang dijual pada beberapa tempat di Kota Padang, didapatkan 20 sampel bakso dinyatakan positif mengandung formalin. 
DAFTAR PUSTAKA

1. Mufti. Cara sehat nikmati makanan, 2012 (diunduh 18 April 2013). Tersedia dari: URL: HYPELINK

http://uniqpost.com/38882/cara-sehat-nikmatimakanan-cepat-saii/.

2. Damiyati N. Ada Pengenyal bakso selain boraks, 2006 (diunduh 11 April 2013). Tersedia dari: URL: HYPERLINK

http://www.suaramerdeka.com/cybernews/harian/ 0601/12/dar16.htm.

3. Depkes RI. Bahaya zat-zat additif. Buletin Infarkes Edisi V-Oktober 2009. Direktorat Jenderal Bina Kefarmasian dan Alat Kesehatan; 2009

4. IARC. Formaldehyde, 2-butoxyethanol and 1-tertbutoxy-2-propanol. IARC monographs on the evaluation of carcinogenic risks to human. 2004; 88.

5. Widianarko B, Pratiwi R, Retnaningsih C. Teknologi produk, nutrisi, dan keamanan pangan.
Jurnal Seri IPTEK Pangan. Semarang. 2000;1.

6. Judarwanto W. Pengaruh formalin bagi sistem tubuh. 2006 (diunduh 3 Mei 2013). Tersedia dari : URL: HYPERLINK http://puterakembara.org/archives8/00000066.sht $\underline{\mathrm{ml}}$.

7. Yuliarti N. Awas bahaya di balik lezatnya makanan. Yogyakarta: Andi Offset; 2007.

8. Winarno FG. Kimia pangan dan gizi. Jakarta: PT Gramedia Pustaka Utama; 2002.

9. Saraswati, Tyas R. 2009. Penelitian pengaruh formalin, diazepam, dan minuman beralkohol terhadap sistem tubuh. 2009 (diunduh 11 Mei 2013). Tersedia dari: URL: HYPERLINK http://ejournal.undip.ac.id/index.php/sm/article/do wnload/3279/2943.

10. Ester, F, Alvama P, Oentoro CP, Setiawan A. Uji kandungan formalin dengan gelombang ultrasonik. Jurnal Program Kreativitas Mahasiswa, Universitas Kristen Satya Wacana; 2011. 